Polish agriculture

\section{Plans for foundation impeded}

POLAND's controversial "agricultural foundation", sponsored by the Roman Catholic Church, which plans to raise money in the West to inject new technology into Polish agriculture, has run into further trouble. The original scheme would have benefited only private farmers, since the 25 per cent of land in the "socialized" sector has for many years received massive government investment. But Polish sources now report that the government is pressing for a proportion of the fund to go to socialized agriculture.

Since the idea of the foundation was first mooted four years ago, government negotiators have shown every sign of trying to block progress. Meetings with Church representatives have been postponed on every conceivable excuse, ranging from the "wars of the Crosses" (protests by secondary school children about the removal of crucifixes from their classrooms) to the murder of Father Jerzy Popieluszko.

Even after the enabling legislation for the foundation was passed in autumn 1984, the wrangling continued. Under the terms of the foundation, an initial $\$ 28 \mathrm{mil}$ -

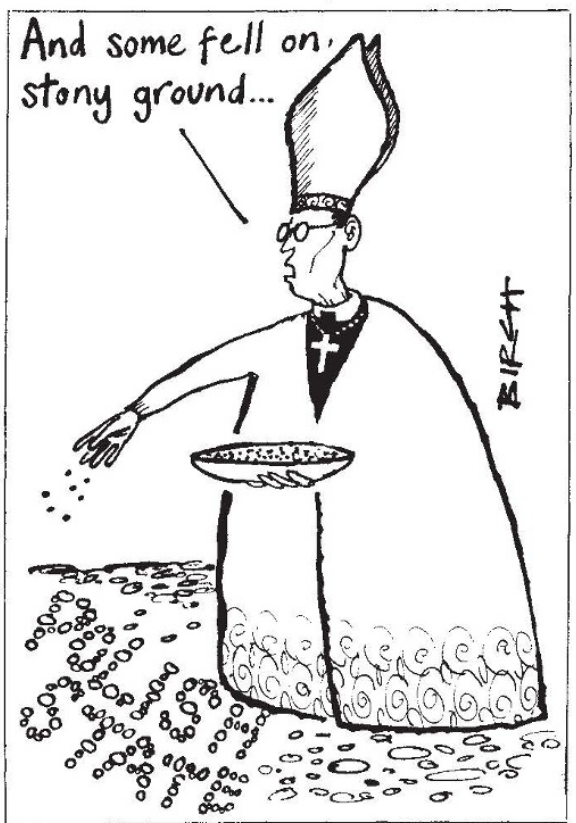

lion was raised for pilot studies, and ten projects were worked out, including water development, agricultural field services, milk production and tractor repairs. But the government was reluctant to let work begin on any of these until the whole cost of the planned rescue operation $(\$ 1,800$ million over five years) had been raised.

Another cause of dispute was the foundation's plan to import agricultural machinery and supplies, purchased for hard currency, and to sell them to farmers at current market prices, but for zloty, partly on a deferred payment basis. (The zloty fund so created would eventually be used for in-country investments such as artesian wells and for improving the social infrastructure in rural areas.) The Church wished the imports to be duty-free; the State pressed for the payment of the full rate of duty. Shortly before the parliamentary elections last autumn, the government seemed prepared to concede this point, with the unspoken quid pro quo that the Church would not encourage the calls for a boycott of the elections. When the bishops themselves stayed away from the elections, the attitude of the government hardened perceptibly.

By the beginning of this year, a new point of contention was raised. The gov-

\section{US agriculture}

Washington

THE new biotechnology should allow the United States to continue meeting domestic food requirements and to contribute significantly to world food demand over the next 20 years, according to a new report* by the Office of Technology Assessment (OTA). But the same technologies could also exacerbate a trend towards fewer and larger farms, unless Congress takes action to prevent it.

OTA estimates that a 1.8 per cent annual increase in world food production is needed to meet demand by the year 2000 , and 83 per cent of this increase has to be from increased production through new technology. OTA agrees with other studies that animal production is likely to be the first to benefit from genetic engineering and other new techniques; plant biotechnology will also benefit, while information technology should allow improved crop and herd management.

Under the most likely assumptions, including application of new technology, OTA estimates that food production could increase by 2 per cent per year. But if the utilization of new technology were significantly less than that OTA thinks most likely, the goal necessary to meet world demand would not be met.

The very detailed report appears to have received a favourable reaction in the US Department of Agriculture. But its most controversial conclusions - because they have immediate consequences for domestic policy - are those relating to different types of farms. OTA argues that very large farms (annual sales of more than $\$ 250,000$ ) will be well able to apply the new technologies by themselves, whereas moderate and small farms will be less able to do so without targeted help from the government. As a result, the ernment hinted that the $\$ 200,000$ pledged to it by Mr Lech Walesa (his 1982 Nobel peace prize winnings) would "politicize" the fund irretrievably. A face-saving formula was worked out by which the organizing committee "relieved $\mathrm{Mr}$ Walesa of the moral obligations he undertook when he donated the prize to the foundation" and Walesa himself decided to withdraw his winnings.

A Vatican Radio communique which announced the organizing committee's decision at the end of February was couched in terms suggesting that, once this matter is resolved, the foundation could implement the pilot projects. But the new demand that "socialized agriculture" should have a share of the fund suggests that the Polish government is still set on prolonging the negotiations as long as possible.

\title{
More food, but fewer farms
}

relative competitive advantage enjoyed by large farms will increase as technology advances. OTA predicts that the number of farms will fall from 2.2 million in 1982 to 1.2 million by the year 2000 . The number of small farms (less than $\$ 100,000$ annual sales) would fall from 60 to 50 per cent .

Some have questioned this prediction: Dr William Brown, chairman of the National Academy of Sciences' Board on Agriculture, believes that the rate of disappearance of small farms is exaggerated in the report

The report is timely: Congress is in the process of considering the administration's proposed agriculture research budget for the coming fiscal year. $\mathrm{Re}$ search and development in the Department of Agriculture would (in dollar terms) be hit harder under the proposed budget than almost any other department; however, the reductions are concentrated in the extension services and in programmes targeted to local problems, which the administration has long held should be paid for by local and State governments. Competitive grants in the agricultural research service - which addresses long-term research - are protected. Congress has previously resisted attempts to cut local agricultural applied research, and the House of Representatives' subcommittee dealing with appropriations for agriculture last week made clear its concern about the extent of proposed reductions: some programmes would take cuts of 60 per cent, others would disappear completely. But with the GrammRudman deficit reduction act in place, all bets are off over how Congress will act.

Tim Beardsley

* Technology, public policy and the changing structure of American agriculture. Office of Technology Assessment, 1986 